\title{
A Predictive Model for Maceral Discrimination by Means of Raman Spectra on Dispersed Organic Matter: A Case Study from the Carpathian Fold-and-Thrust Belt (Ukraine)
}

\author{
Andrea Schito ${ }^{1,2, *(\mathbb{D}}$, Alexandra Guedes ${ }^{3}{ }^{-}$, Bruno Valentim $\left.{ }^{3}{ }^{(}\right)$, Natalia A. Vergara Sassarini ${ }^{1}$ \\ and Sveva Corrado ${ }^{1}$ \\ 1 Dipartimento di Scienze, Sezione Scienze Geologiche, Università degli Studi di Roma Tre, Largo San Leonardo \\ Murialdo, 1, 00146 Rome, Italy; amanda.vergara@uniroma3.it (N.A.V.S.); sveva.corrado@uniroma3.it (S.C.) \\ 2 Department of Geology and Petroleum Geology, School of Geosciences, University of Aberdeen, \\ Aberdeen AB24 3UE, UK \\ 3 Insituto da Ciências da Terra e Departamento de Geosciências, Ambiente e Ordenamento do Territòrio, \\ Faculdade de Ciências, Universidade do Porto, 4169-007 Porto, Portugal; aguedes@fc.up.pt (A.G.); \\ bvvalent@fc.up.pt (B.V.) \\ * Correspondence: andrea.schito@abdn.ac.uk
}

Citation: Schito, A.; Guedes, A.; Valentim, B.; Vergara Sassarini, N.A.; Corrado, S. A Predictive Model for Maceral Discrimination by Means of Raman Spectra on Dispersed Organic Matter: A Case Study from the Carpathian Fold-and-Thrust Belt (Ukraine). Geosciences 2021, 11, 213. https://doi.org/10.3390/ geosciences 11050213

Academic Editors: Ian Coulson and Jesus Martinez-Frias

Received: 24 March 2021

Accepted: 7 May 2021

Published: 14 May 2021

Publisher's Note: MDPI stays neutral with regard to jurisdictional claims in published maps and institutional affiliations.

Copyright: (c) 2021 by the authors. Licensee MDPI, Basel, Switzerland. This article is an open access article distributed under the terms and conditions of the Creative Commons Attribution (CC BY) license (https:// creativecommons.org/licenses/by/ $4.0 /)$.

\begin{abstract}
In this study, we propose a predictive model for maceral discrimination based on Raman spectroscopic analyses of dispersed organic matter. Raman micro-spectroscopy was coupled with optical and Rock-Eval pyrolysis analyses on a set of seven samples collected from Mesozoic and Cenozoic successions of the Outer sector of the Carpathian fold and thrust belt. Organic petrography and Rock-Eval pyrolysis evidence a type II/III kerogen with complex organofacies composed by the coal maceral groups of the vitrinite, inertinite, and liptinite, while thermal maturity lies at the onset of the oil window spanning between 0.42 and $0.61 \mathrm{R}_{\mathrm{o}} \%$. Micro-Raman analyses were performed, on approximately 30-100 spectra per sample but only for relatively few fragments was it possible to perform an optical classification according to their macerals group. A multivariate statistical analysis of the identified vitrinite and inertinite spectra allows to define the variability of the organofacies and develop a predictive PLS-DA model for the identification of vitrinite from Raman spectra. Following the first attempts made in the last years, this work outlines how machine learning techniques have become a useful support for classical petrography analyses in thermal maturity assessment.
\end{abstract}

Keywords: Raman spectroscopy; dispersed organic matter; vitrinite reflectance; principal component analysis; partial least square discriminant analysis; machine learning

\section{Introduction}

The analysis of coals and dispersed organic matter (DOM) is an irreplaceable tool in thermal maturity assessment and environmental studies of sedimentary successions [1]. In thermal model calibration for petroleum exploration and basin analysis, vitrinite reflectance is still the most accurate and reliable indicator [2-5]. On the other hand, vitrinite discrimination among different organic facies has always been a critical issue for a correct assessment of thermal maturity [6,7], in particular when other low reflecting macerals occur [8-11]. Given this and the occurrence of other pitfalls that can interfere with vitrinite reflectance assessment (e.g., suppression and retardation [12,13] and references therein), alternative methods have been proposed, such as palynomorph darkness index (PDI, [14,15]), FT-IR spectroscopy [16-20], NMR [21], XPS [22], or Raman spectroscopy [23-33].

In the last years, an increasing interest in the application of Raman spectroscopy for thermal maturity assessment in catagenesis and metagenesis [24,26,27,29,31,34-38] has been observed. The majority of articles focused on the analysis of single macerals, mainly vitrinite in coals $[24,26,27]$, whereas other ones on bulk kerogen [29,34,38]. Nevertheless, 
only a few authors dealt with the heterogeneity that can characterize organic facies [23,32] or even a single organoclast [37,39].

Most of the works dealing with Raman spectra of kerogen use a classic band fitting approach that in many cases can result in biased results, as recently outlined [36,40]. Thus, different automatic approaches have been proposed based on simplified band deconvolution $[31,38,41]$ or on a multivariate analysis chemometric scheme [34,36] for the spectra analysis, proposing a challenging approach for geological studies. In particular, a principal component analysis (PCA)-partial least square (PLS)-based multivariate analysis has been recently proposed [34,36] to correlate predictive parameters from PLS regression against vitrinite reflectance. Moreover, Schito et al. [32] demonstrated how a partial least square discrimination analysis (PLS-DA) allows to define and predict the differences between vitrinite and sporomorphs on the base of their Raman spectrum for a given thermal maturity degree.

In this work, we test a similar approach on a set of seven samples collected in the Outer sector of the Carpathian Fold and Thrust belt (Ukraine), in order to define quantitatively the differences in Raman spectra between vitrinite and inertinite group macerals and predict them with the aim to provide a more robust dataset for thermal maturity assessment.

\section{Materials and Methods}

\subsection{Materials}

Samples were collected from black shales at various stratigraphic intervals (Early Cretaceous to Early Miocene) cropping out in the Outer Carpathians, in SW Ukraine, close to the Romania border (Figure 1). This portion of the fold-and-thrust belt shows an imbricate fan architecture made up of a series of NE-verging thrust sheets [42] in which three tectonic units are recognized (Boryslav-Pokuttia tectonic Unit, Skiba tectonic Unit and Chornogora tectonic Unit, Figure 1). In detail, five samples (PL 93.1, PL 93.2, PL 95, PL 97, PL 101.1) come from organic-rich levels of the Melinite shales (Oligocene to Lower Miocene) cropping out in the Skiba Unit. Sample PL 102 was collected in a pelitic bed of the Eocene-Oligocene succession of the Globigerina Marls in the Skiba Unit, whereas sample PL 103 comes from an organic-rich level of the Hauterivian-Albian Spas-Shypot formation in the Chornogora Unit (Figure 1).
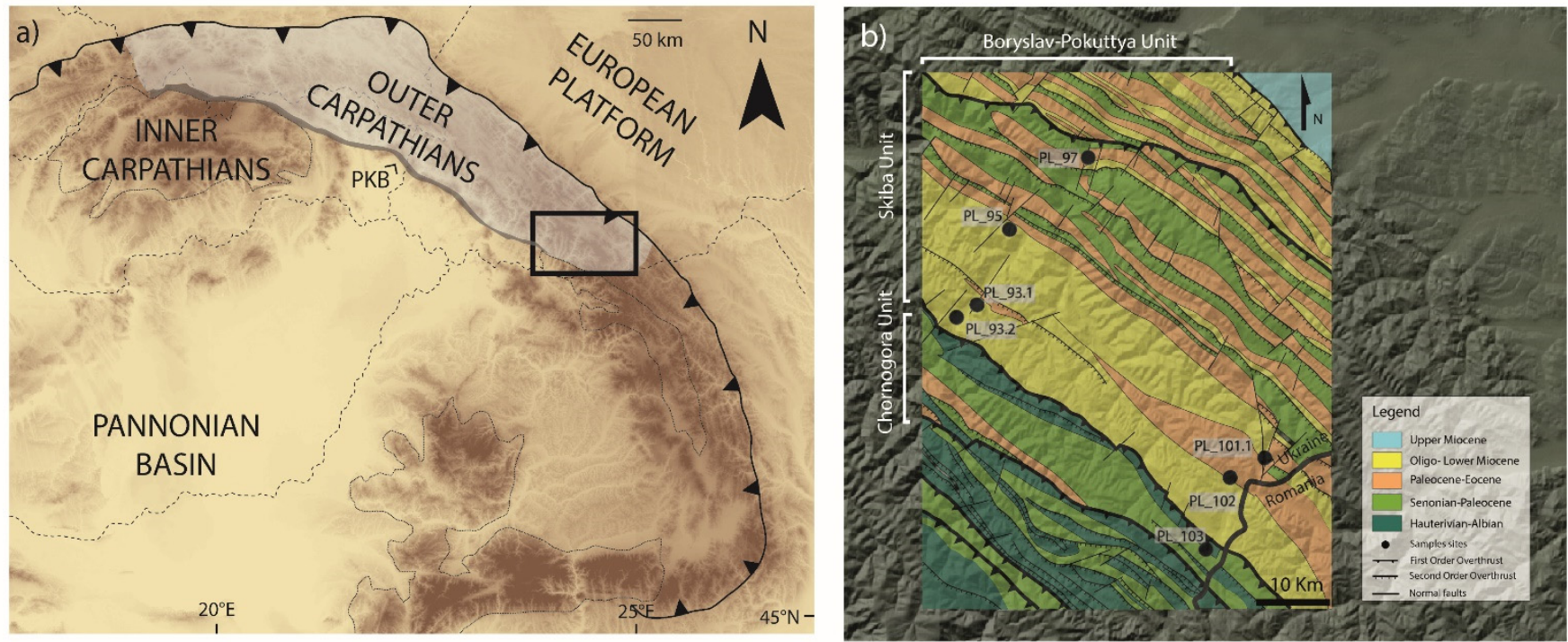

Figure 1. Geographic and geologic setting of the studied area: (a) Simplified tectonic sketch of the Carpathians, in the square the b map location. PKB: Pieniny Klippen Belt. (b) Geological map of the sampled area. Black dots indicate sampled sites. Redrawn from the "Geological map of the outer Carpathians: borderland of Ukraine and Romania. 1:200,000" [43]. 


\subsection{Rock-Eval Pyrolysis}

Rock-Eval pyrolysis is a traditional quantitative method for kerogen characterization, based on the relative intensity and distribution of three fluid peaks (S1, S2, S3), artificially generated at different lab temperatures from a whole rock specimen containing kerogen. Free hydrocarbons (S1) in the rock and the amount of hydrocarbons (S2) expelled during pyrolysis and TOC were measured using a Rock-Eval 6 equipment at ENI laboratories [44].

\subsection{Vitrinite Reflectance Analysis}

Samples were prepared for petrographic analysis via $\mathrm{HCl}-\mathrm{HF}$ digestion to remove carbonates and silicates [45] and after, concentrated organic residue was prepared as polished blocks following ASTM standards [46]. The vitrinite mean random reflectance was measured at the University of Porto (Portugal) on a reflected light Leitz microscope coupled to a Diskus-Fossil System following ASTM standard D7708-14 [47].

\subsection{Raman Spectroscopy}

Micro-Raman spectroscopic analyses were performed on organic particles, some of them identified as vitrinite or inertinite, observed under reflected light on polished sections. Micro-Raman spectroscopy was carried out at the University of Porto (Portugal) using a Horiba Jobin-Yvon LabRam XploRA ${ }^{\mathrm{TM}}$ system in a backscattering geometry, in the range of $700-2300 \mathrm{~cm}^{-1}$ using a 1200 grooves / mm spectrometer gratings and CCD detector. The instrument is equipped with $50 \times$ and $100 \times$ objective lens, and an excitation wavelength of $532 \mathrm{~nm}$ from a Nd:YAG laser at a power of $25 \mathrm{~mW}$. To avoid laser-induced degradation of kerogen and reduce the fluorescence background to minimal values, laser power was adjusted below $0.4 \mathrm{~mW}$, using optical filters and the Raman backscattering was recorded after an integration time of $20 \mathrm{~s}$ for 6 repetitions. Each organic particle was analysed with an about $1 \mu \mathrm{m}$ diameter spot using a 50× optical power objective, and about 30-100 measures for samples were performed depending on the abundance of organic particles.

Raman spectra of organic matter appear in the first order region between $1000 \mathrm{~cm}^{-1}$ and $1800 \mathrm{~cm}^{-1}$, whereas bands in the second order region, between $2000 \mathrm{~cm}^{-1}$ and $3500 \mathrm{~cm}^{-1}$, were not detected since they are weak in low matured organic matter and can be only detected using shorter Raman excitation wavelengths (e.g., less than $488 \mathrm{~cm}^{-1}$ ). The first order Raman spectra consists of two main bands known as the $D$ and the $G$ bands [48] and by other bands depending on the degree of the coal rank [49,50]. The G band is related to the in-plane vibration of the carbon atoms in the graphite sheets, while the $\mathrm{D}$ band at $1350 \mathrm{~cm}^{-1}$ becomes active in disordered graphite and has been interpreted as a results of a double resonant Raman scattering process [51-53] or alternatively as the ring breathing vibration in the graphite sub-unit or polycyclic aromatic compounds (PAHs; [54-58]). On the other hand, no general consensus has been reached regarding the assignment of the other bands that compose the first order Raman spectra of carbonaceous materials. Two bands at $1150 \mathrm{~cm} \mathrm{~cm}^{-1}$ and at $1250 \mathrm{~cm} \mathrm{~cm}^{-1}$ ( $\mathrm{S}$ and $\mathrm{Dl}$ in [29,58]) were assigned by [59] (called in their work D4 and D5 bands, see Table 1) to C-H species in aliphatic hydrocarbon, while other authors $[55,58]$ assigned them respectively to polyacetylene-like structures and low size aromatic domains. Moreover, band at $1465 \mathrm{~cm}^{-1}$ and $1380 \mathrm{~cm}^{-1}$, which represent the "overlap" between D and G (Dr and Gl bands in $[29,58]$ ), were assigned mainly to amorphous carbon structures in char (D3 band by [60]), small ring systems (e.g., with 3-5 fused benzene rings) by [55] and [58] and polyacetylene-like structures. Alternatively, a band at around $1500 \mathrm{~cm}^{-1}$ was assigned to trapped hydrocarbons by [61] (D5 band in their work). See Table 1 for a complete review. 
Table 1. First-order Raman bands and vibration modes reported by different authors. Raman shift are approximated and bands name can change according to different authors interpretations.

\begin{tabular}{|c|c|c|c|}
\hline Raman Shift $\left(\mathrm{cm}^{-1}\right)$ & Band & Vibrational Mode & Authors \\
\hline$\sim 1580 \mathrm{~cm}^{-1}$ & G & $\begin{array}{l}\text { In-plane vibration of the } \\
\text { carbon atoms } \\
\text { in the graphene sheet } \\
\left(\mathrm{E}_{2 \mathrm{~g}} \text {-symmetry) }\right.\end{array}$ & $\begin{array}{l}\text { Tuinstra and Koening, } 1970 \\
\text { Reich and Thomsen, } 2004\end{array}$ \\
\hline \multirow[b]{2}{*}{$\sim 1500 \mathrm{~cm}^{-1}$} & Gl & Polyacetylene like structures & Rebelo et al., 2016 \\
\hline & D3 & $\begin{array}{l}\text { Out-of-plane tetrahedral } \\
\text { carbons in } \\
\text { amorphous carbon }\end{array}$ & Sadezky et al., 2005 \\
\hline \multirow{2}{*}{$\sim 1400 \mathrm{~cm}^{-1}$} & $\mathrm{Dr}$ & Low size aromatic domains & Castiglioni et al., 2001 \\
\hline & D5 & Trapped hydrocarbons & Romero-Sarmiento et al., 2014 \\
\hline \multirow{3}{*}{$\sim 1350 \mathrm{~cm}^{-1}$} & D1 & $\begin{array}{l}\text { Disordered graphitic lattice } \\
\qquad\left(\mathrm{A}_{1 \mathrm{~g}} \text { symmetry }\right)\end{array}$ & Tuinstra and Koening, 1970 \\
\hline & $\mathrm{D}$ & $\begin{array}{l}\text { Ring breathing vibration } \\
\text { in PAHs }\end{array}$ & Castiglioni et al., 2001 \\
\hline & D1 & $\begin{array}{l}\text { Double resonant Raman } \\
\text { scattering process }\end{array}$ & Reich and Thomsen, 2004 \\
\hline \multirow{2}{*}{$\sim 1300 \mathrm{~cm}^{-1}$} & $\mathrm{Dl}$ & Low size aromatic domains & Castiglioni et al., 2001 \\
\hline & D5 & $\begin{array}{l}\text { C-H species in aliphatic } \\
\text { hydrocarbon chains }\end{array}$ & Ferralis et al.,2016 \\
\hline \multirow{3}{*}{$\sim 1200 \mathrm{~cm}^{-1}$} & $\mathrm{~S}$ & Polyacetylene like structures & Rebelo et al., 2016 \\
\hline & D4 & $\begin{array}{l}\text { Disordered graphitic lattice } \\
\left(\mathrm{A}_{1 \mathrm{~g}} \text { symmetry) or polyene }\right.\end{array}$ & Sadezky et al., 2005 \\
\hline & D4 & $\begin{array}{l}\text { C-H species in aliphatic } \\
\text { hydrocarbon chains }\end{array}$ & Ferralis et al.,2016 \\
\hline
\end{tabular}

\subsection{Multivariate PCA and PLS-DA Analyses on Raman Spectra}

Statistical principal component analysis (PCA) and partial least square discriminant analysis (PLS-DA) were performed in the range of Raman spectra between $1000 \mathrm{~cm}^{-1}$ and $2000 \mathrm{~cm}^{-1}$. The ranges between 700 and $1000 \mathrm{~cm}^{-1}$ and between 2000 and $2300 \mathrm{~cm}^{-1}$ in the original spectra have been excluded from the PCA analysis since they do not contain relevant information and can only add a further source of error. Before performing PCA and PLS-DA, all spectra were pre-processed for spike removal and spectra normalization (relatively to the maximum intensity of the G band). The PCA routine of MATLAB R2017b software (The MathWorks, Natick, MA, USA) was used. The main purpose of PCA is to reduce the dimensionality of a multivariate dataset by explaining the variance-covariance structure of the data using a linear combination of the original variables to form principal components (PCs), minimizing the information loss. In this work we use the PCA to examine the qualitative differences within Raman spectra finding the maximum differences among them in the PC space (the space where the component scores correspond to the coordinates of each observation). In the case of Raman spectra, observations are represented by the number of measurements for each sample and the original variables (frequencies of the Raman spectra, in this case 1021 for each spectrum). The projection of the observations on the PC space is called "component score", while the weight of each original variable in the new space is called "loading". A score plot gives information about the relationship between observation (spectra), while loading explains which variables (i.e., frequencies) are responsible for the separation observed in the score plot.

PLS-DA was used to develop classification rules for macerals that cannot be optically ascribed to a maceral group. A spectral dataset, consisting of optically identified vitrinite 
and inertinite spectra, was used as the training set to develop a calibration model and find the predicting parameters that were used to classify a testing set. The testing set here is represented by the whole dataset of Raman spectra for which an optical classification was impossible in terms of recognisable macerals. PLS-DA on the training set, is a supervised classification since it is based on an external a priori classification (dependent variable). In this case the dependent variable is represented by the belonging to two different groups (group 1 for the vitrinite, and group 2 for the inertinite). The calibration of the training set produces a set of regression coefficients from which the predicted values of the dependent variables are computed. The relation between independent and dependent variables in the training set is given by the beta coefficients. Multiplying the beta coefficient by the independent variables allows to predict the unknown dependent variables for the testing set.

Figure 2 shows an example of the workflow developed in this work. Starting from the raw spectra, we use the PCA score plot to identify the distribution of our data. Then, we identify where the optically recognized macerals fall in the score plot and improve their number through PLS-DA analysis. Finally, all $\mathrm{R}_{\mathrm{o}} \%$ equivalent values are calculated for the identified macerals. In Figure 2, we show as an example also the reflectance equivalent values of inertinite, while the focus of this work is to find reflectance equivalent values only for vitrinite fragments (see discussion section).

\section{Normalized Raman spectra}
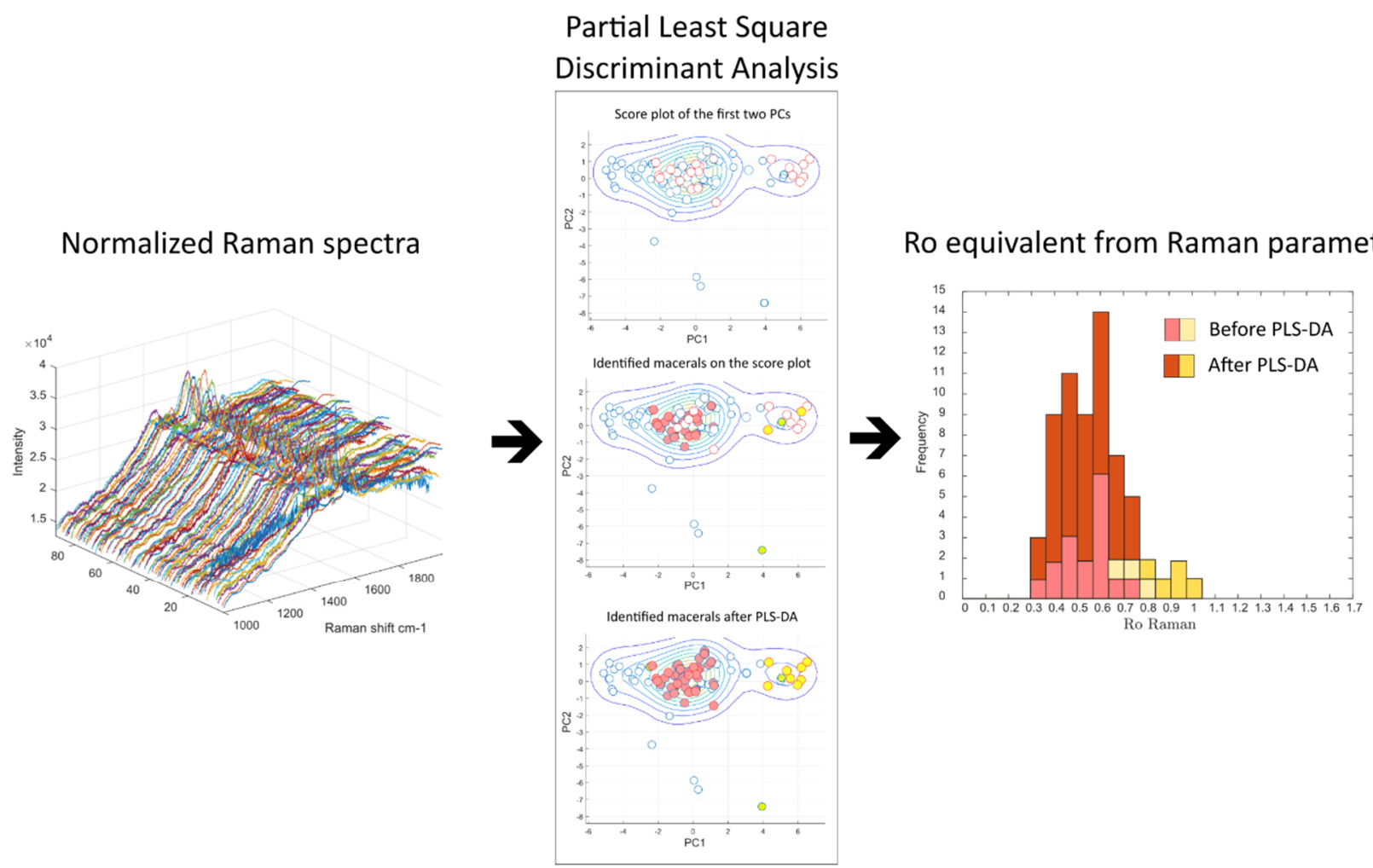

Figure 2. Workflow of the supervised classification used to identify vitrinite spectra. Original spectra have been plotted after PCA analysis on a score plot where identified macerals (vitrinite and inertinite) have been put in evidence before and after PLS-DA analysis (red dots for vitrinite and yellow dots for inertinite). Frequency histogram to the right shows reflectance equivalent values calculated before and after PLS-DA on different macerals (red bins for vitrinite, yellow bins for inertinite).

\section{Results}

\subsection{Rock-Eval Pyrolysis}

Results from Rock Eval pyrolysis and TOC are listed in Table 2 and plotted in Figure 3 on a pseudo-Van Krevelen diagram based on HI and Tmax measurement [62]. 


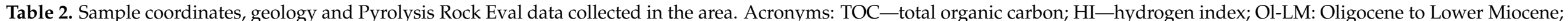

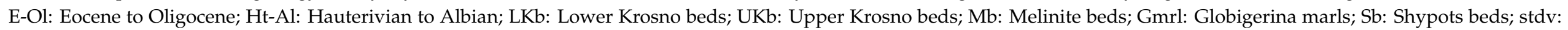
standard deviation; $\mathrm{n}^{\circ}$ : number of measurements.

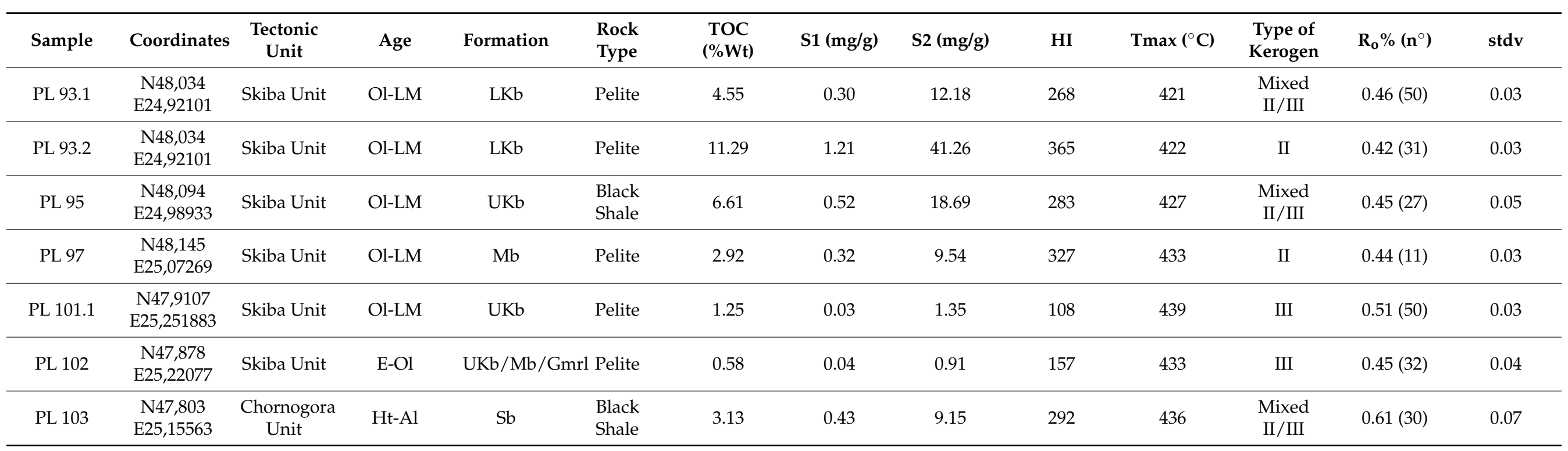




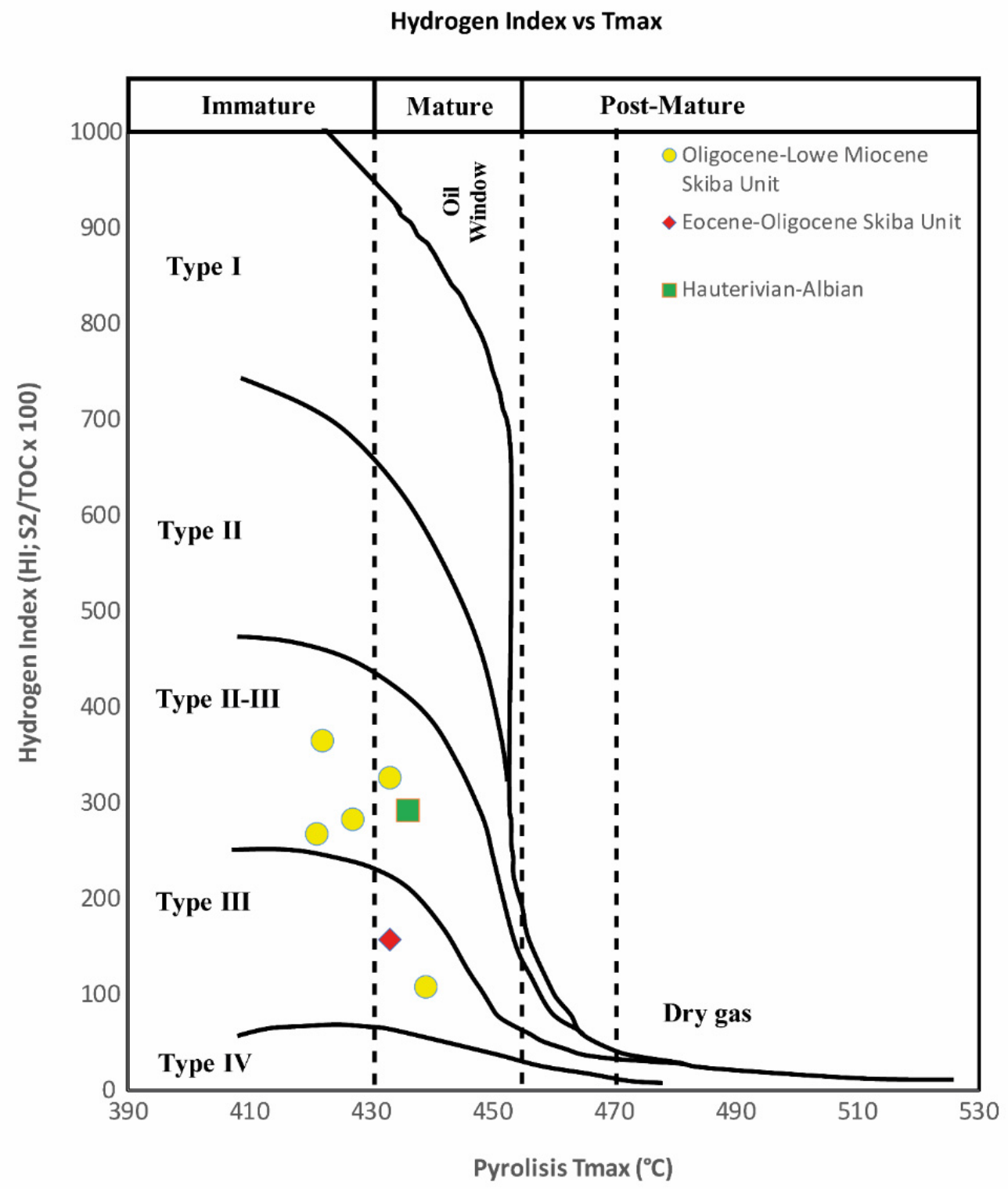

Figure 3. Kerogen classification of the studied samples according to pseudo Van Krevelen diagram, where Tmax vs. HI derived from Rock-Eval Pyrolysis are plotted (redrawn after [62]).

As shown in Table 2 and Figure 3, the Rock-Eval results indicate type II - III kerogen. TOC and HI, ranging between 0.58 and $11.29 \%$ and 108 and 365, respectively, are typical of good to excellent source rocks. The highest TOC and HI values characterise pelites and black shales from the Krosno Beds and Lower Cretaceous Shypot formation (Chornogora Unit). Tmax values range between $421^{\circ} \mathrm{C}$ and $439^{\circ} \mathrm{C}$ indicating roughly the immature and the early stages of HC generation.

\subsection{Organic Petrography and Vitrinite Reflectance $\left(R_{o} \%\right)$}

Concentrated organic matter concentrates, observed under incident light, is composed by different macerals with different reflectance values (Figure $4 c, d$ as an example and Supplementary Figures in Plate A). 

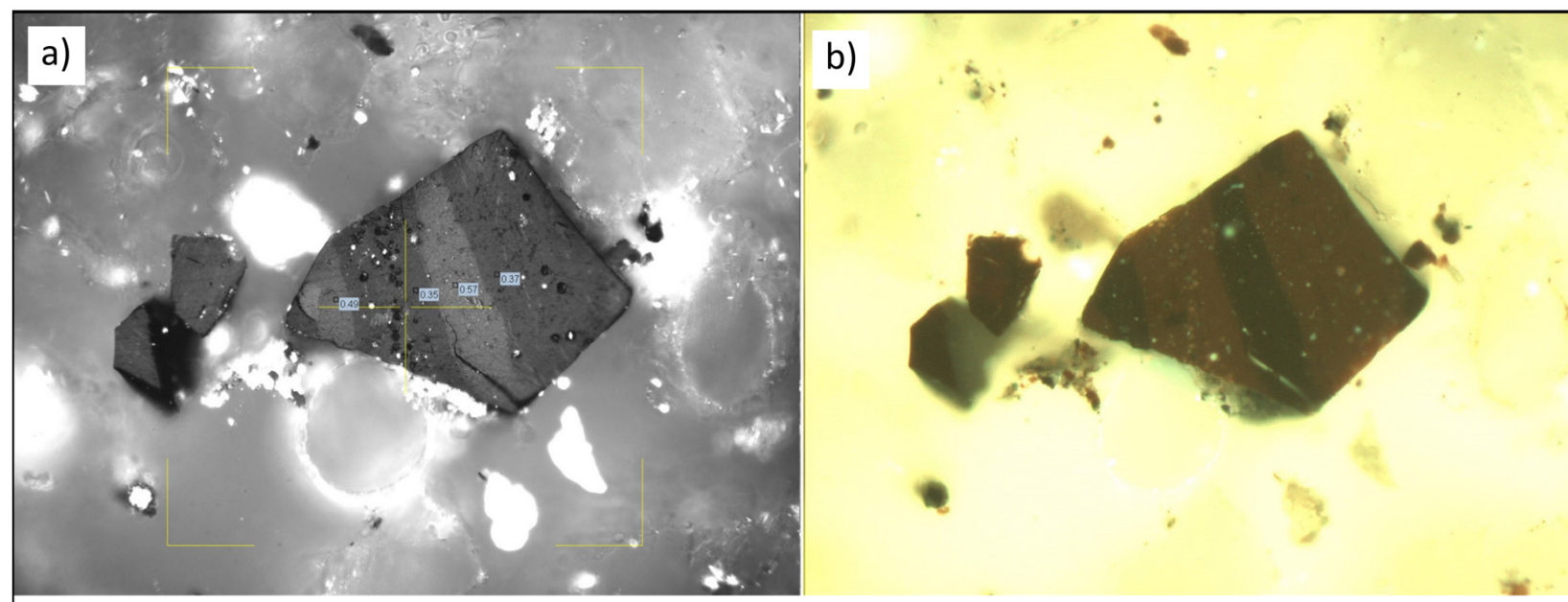

\section{c) $\mathbf{R}_{\circ} \%$ on visible macerals}

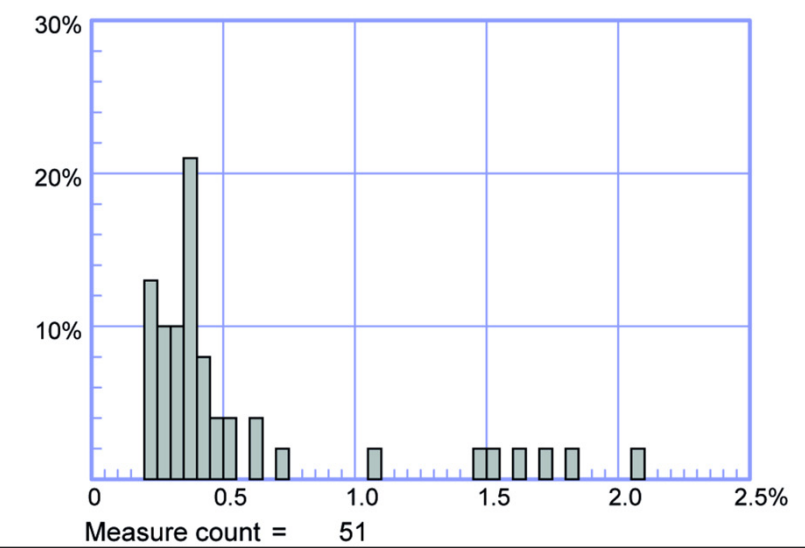

d) $\mathbf{R}_{\circ} \%$ on vitrinite

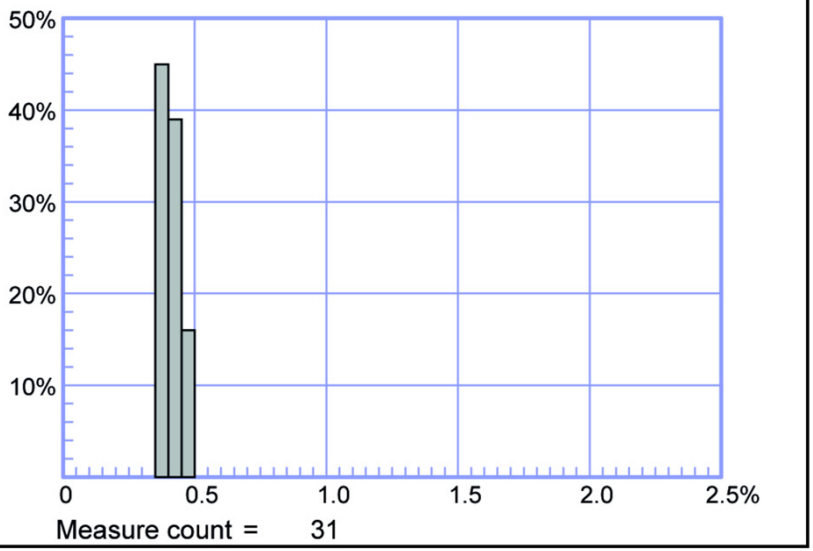

Figure 4. Examples of reflected light images of the analysed macerals: (a) Lithotype composed by vitrinite (light portion of the fragment) and liptinite (dark part); (b) same fragment of figure A observed under fluorescent light. It can be noted the weak brownish fluorescence of liptinite. Example of a Random Reflectance histogram showing: (c) reflectance of all visible macerals and (d) only vitrinite in the same sample.

In reflectance histograms comprising all macerals (Figure $4 \mathrm{c}$ as an example and Supplementary Materials Plate A for all results), $R_{0} \%$ values span across a wide range between about $0.2 \%$ and $2.0 \%$. The lowest values $\left(0.2<\mathrm{R}_{\mathrm{o}} \%<0.35\right)$ were measured on dark grey fragments with low contrast to inorganic matrix under white light, which were interpreted as liptinite. These fragments often show a heterogeneous texture and can be sometimes confused with vitrinite fragments, but they can be distinguished thanks to their brown fluorescence, under fluorescent blue-light (Figure $4 b$ ).

Vitrinite fragments were recognized on the base of morphological features and reflectance distribution in frequency histograms. $R_{o} \%$ values range between about $0.40 \%$ and $0.60 \%$ (Table 1 ).

The histograms showing reflectance values from all macerals (Supplementary Materials Plate A) indicate that vitrinite is the most abundant maceral in almost all the samples, with exception for samples PL 95 and PL 97.

High reflectance values can correspond to reworked vitrinite but also to macerals belonging to the inertinite group (es. semifusinite and fusinite). Fusinite generally shows reflectance higher than $1.0 \%$ while reflectance values around $0.7-0.8 \%$, in some cases close to those of vitrinite fragments (e.g., sample PL 103), correspond to semifusinite. 


\subsection{Micro-Raman Spectroscopy}

\subsubsection{Raman Spectra and Raman Parameters}

The normalized Raman spectra of each sample are shown in Figure $5 \mathrm{a}, \mathrm{b}$ and in Supplementary Materials Plate B. As shown in the figures, there is a high heterogeneity in Raman spectra. Most of them show a high fluorescence background, a wide $G$ band and a low intensity D band (high D/G intensity ratio). Nevertheless, spectra with a narrow $G$ band and a D band shifted toward lower wavenumbers and lower fluorescence background are also present.
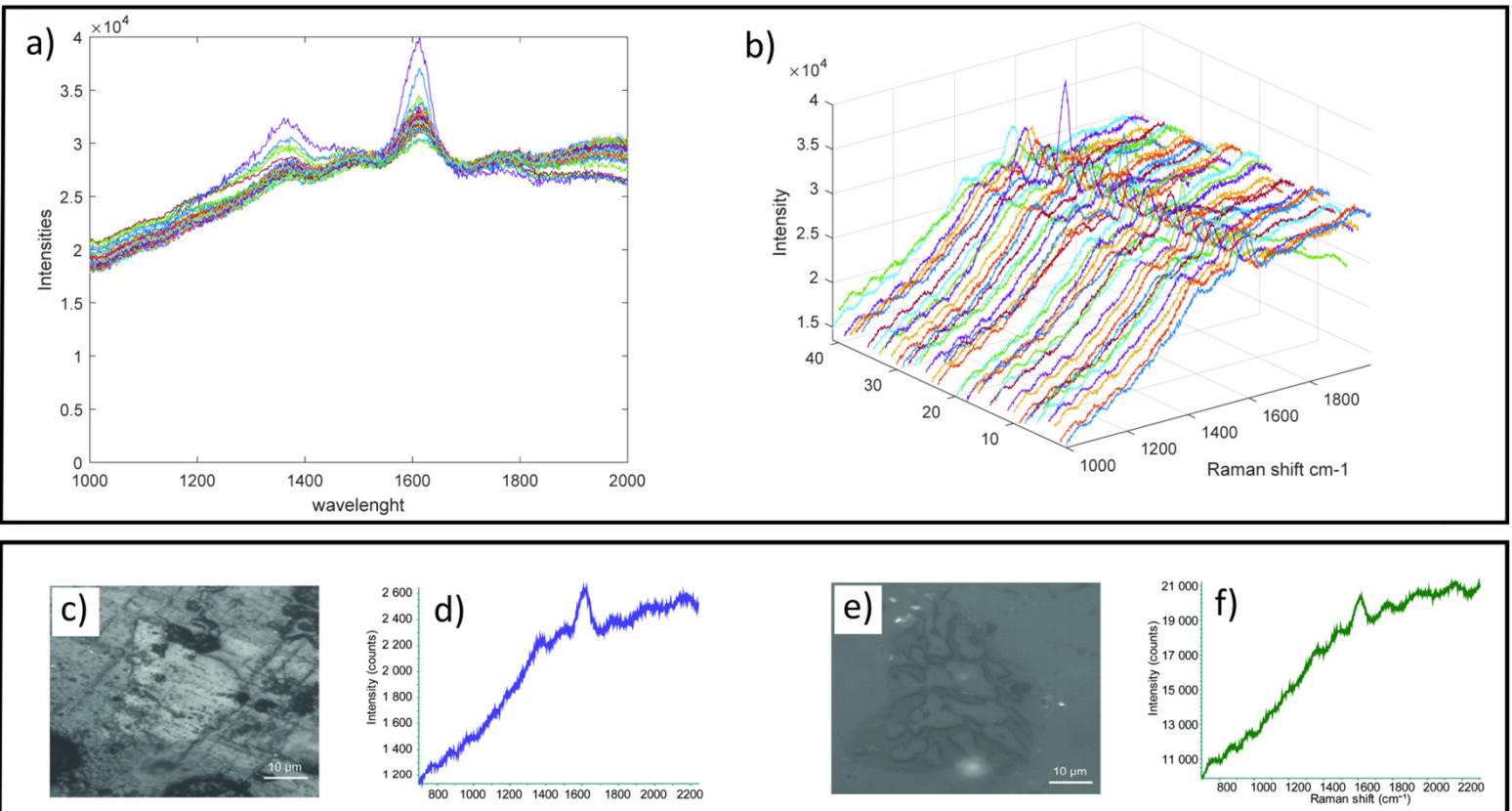

Raman shit (cm-)
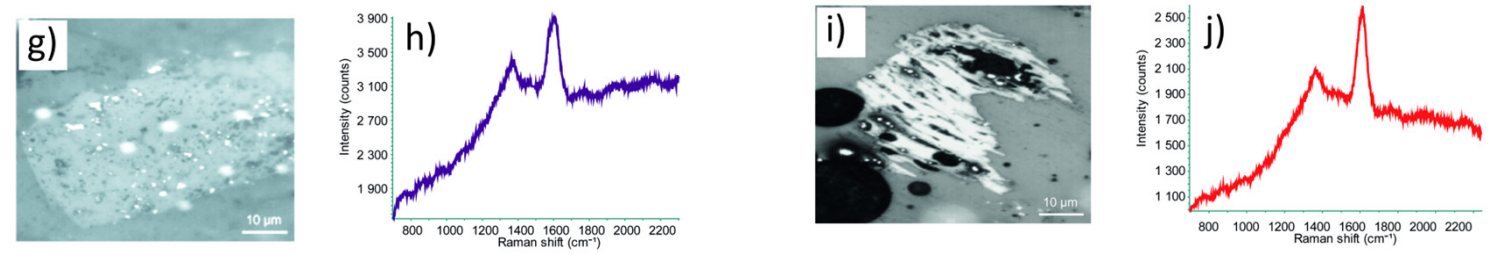

Figure 5. Example of normalized spectra in 2D (a) and 3D (b) view acquired on sample PL 93.1. Raman spectra of different macerals analysed (each Raman spectrum was measured on a 2 micron spot located at the center of the image): (c) microphotograph of a maceral recognized as belonging to the vitrinite group and (d) its related spectrum; (e) possible liptinite macerals with (f) a high fluorescence spectrum; (g) microphotograph of a maceral recognized as semifusinite and (h) its related spectrum; (i) microphotograph of a maceral recognized as belonging to the inertinite group and (j) its related spectrum. Note that lighting is not the same for each photo.

Micro-Raman measurements were performed on discrete organic particles. The identification of different macerals was not easy using an air-immersion objective such as those mounted on the Raman equipment and it was not possible for most of the measured fragments. Nevertheless, in some cases, optical recognition of macerals was possible, as shown in Figure 5c,e,g,i.

Generally, vitrinite fragments appear as low-relief dark-grey ones, usually with a squared or a triangular shape (Figure $5 \mathrm{c}$ ) with a high to moderate fluorescence, depending on the maturity of the sample and a large $G$ band generally more prominent than the $D$ band (Figure 5d). Fragments darker than vitrinite (when observed under the same lighting) with a heterogeneous texture and higher fluorescence Raman spectra could be interpreted 
as liptinite (Figure 5e,f). Nevertheless, the classification of liptinite is prevented by the dark colour being similar to the surrounding matrix and by the high fluorescence that overwhelms the spectrum in most of the cases.

Inertinite fragments are relatively easy to identify but are heterogeneous: semifusinite is more easily recognizable because of its intermediate shade of grey between vitrinite and fusinite and some preserved cell structures, but not as much as in fusinite (Figure $5 \mathrm{~g}$ ). Its spectra (Figure $5 \mathrm{~h}$ ) show low fluorescence with respect to vitrinite and well-defined D and $\mathrm{G}$ bands. Fusinite fragments show a light shade of grey, well preserved cell structure and a similar spectrum to the one of semifusinite, but with lower fluorescence and a narrower $G$ band (Figure $5 \mathrm{i}, \mathrm{j}$ ).

Table 3 shows the results of the mean values of Raman parameters for each sample derived from a separate deconvolution of the D and G band, according to [38].

Table 3. Mean values of Raman parameters for each sample, calculated by means of the automatic deconvolution proposed by Schito and Corrado (2018). pD, position of the $\mathrm{D}$ band $\left(\mathrm{cm}^{-1}\right) ; \mathrm{pG}$, position of the $\mathrm{G}$ band $\left(\mathrm{cm}^{-1}\right)$; $\mathrm{wD}$, full width at the maximum height of the $\mathrm{D}$ band $\left(\mathrm{cm}^{-1}\right)$; $w G$, full width at half maximum of the $\mathrm{D}$ band $\left(\mathrm{cm}^{-1}\right) ; \mathrm{aD}$, integrated area of the $\mathrm{D}$ band; $\mathrm{aG}$, integrated area of the $\mathrm{G}$ band; $\Delta \mathrm{D}-\mathrm{G}$ : difference between $\mathrm{G}$ band and $\mathrm{D}$ band position ( $\mathrm{cm}^{-1}$ ); ID/IG, intensity ratio between the $\mathrm{D}$ and $\mathrm{G}$ bands; $\mathrm{aD} / \mathrm{aG}$, area ratio between the $\mathrm{D}$ and $\mathrm{G}$ bands; $\mathrm{wD} / \mathrm{wG}$, ratio between the full width at half maximum of $\mathrm{D}$ and $\mathrm{G}$ bands.

\begin{tabular}{|c|c|c|c|c|c|c|c|c|c|c|c|}
\hline Sample & $\mathrm{pD}$ & s.d pD & pG & $\begin{array}{l}\text { s.d. } \\
\text { pG }\end{array}$ & wD & $\begin{array}{l}\text { s.d. } \\
\text { wD }\end{array}$ & wG & $\begin{array}{l}\text { s.d. } \\
\text { wG }\end{array}$ & $\mathrm{aD}$ & s.d. aD & aG \\
\hline PL 93.1 & 1359.59 & 5.62 & 1616.91 & 1.43 & 225.96 & 47.16 & 117.75 & 6.64 & $14,441.28$ & 7881.37 & $15,052.34$ \\
\hline PL 93.2 & 1361.29 & 9.06 & 1617.37 & 2.55 & 192.30 & 56.52 & 118.65 & 6.89 & $30,166.66$ & $30,653.46$ & $27,534.29$ \\
\hline PL 95 & 1356.94 & 8.70 & 1616.65 & 1.84 & 222.11 & 49.24 & 132.87 & 7.90 & $48,153.24$ & $14,578.57$ & $73,846.22$ \\
\hline PL 97 & 1364.53 & 3.62 & 1616.60 & 2.67 & 182.02 & 34.33 & 119.99 & 6.50 & $28,237.92$ & $15,814.34$ & $28,118.21$ \\
\hline PL 101.1 & 1351.85 & 4.44 & 1607.29 & 4.30 & 252.44 & 57.36 & 143.24 & 15.57 & $32,410.07$ & $15,889.49$ & $50,086.10$ \\
\hline PL 102 & 1353.76 & 3.92 & 1612.22 & 2.64 & 206.50 & 53.44 & 129.51 & 13.46 & $42,512.17$ & $27,135.25$ & $61,250.41$ \\
\hline PL 103 & 1344.60 & 5.81 & 1609.86 & 2.47 & 246.83 & 46.97 & 120.14 & 6.97 & $76,033.64$ & $37,048.33$ & $93,230.31$ \\
\hline Sample & s.d. aG & $\Delta \mathrm{D}-\mathrm{G}$ & s.d. $\Delta \mathrm{D}-\mathrm{G}$ & ID/IG & $\begin{array}{c}\text { s.d. } \\
\text { ID/IG }\end{array}$ & $\mathrm{aD} / \mathrm{aG}$ & $\begin{array}{c}\text { s.d. } \\
\mathrm{aD} / \mathrm{aG}\end{array}$ & wD/wG & $\begin{array}{c}\text { s.d. } \\
\text { wD/wG }\end{array}$ & $\begin{array}{c}\text { Ro\% } \\
\text { equivalent }\end{array}$ & $\begin{array}{l}\text { s.d. Ro\% } \\
\text { equivalent }\end{array}$ \\
\hline PL 93.1 & 7082.74 & 257.32 & 5.77 & 0.40 & 0.06 & 0.96 & 0.20 & 1.94 & 0.48 & 0.51 & 0.18 \\
\hline PL 93.2 & $18,645.36$ & 256.08 & 7.59 & 0.47 & 0.05 & 1.01 & 0.35 & 1.63 & 0.52 & 0.43 & 0.23 \\
\hline PL 95 & $23,325.32$ & 259.71 & 9.56 & 0.40 & 0.04 & 0.66 & 0.13 & 1.68 & 0.42 & 0.50 & 0.22 \\
\hline PL 97 & $11,977.36$ & 252.07 & 3.49 & 0.48 & 0.07 & 1.01 & 0.30 & 1.52 & 0.31 & 0.35 & 0.07 \\
\hline PL 101.1 & $23,709.26$ & 255.43 & 6.89 & 0.36 & 0.06 & 0.65 & 0.20 & 1.75 & 0.35 & 0.46 & 0.13 \\
\hline PL 102 & $29,505.44$ & 258.46 & 4.57 & 0.43 & 0.10 & 0.72 & 0.27 & 1.62 & 0.48 & 0.48 & 0.15 \\
\hline PL 103 & $43,684.14$ & 265.26 & 6.66 & 0.41 & 0.06 & 0.82 & 0.17 & 2.06 & 0.40 & 0.67 & 0.14 \\
\hline
\end{tabular}

The mean $R_{0} \%$ value is highest in sample PL 103 and lowest in sample PL 97 (Table 3). However, the standard deviation calculated from all values is quite high, reflecting the maceral heterogeneity described above.

The variability of the $\mathrm{R}_{\mathrm{o}} \%$ equivalent calculated from Raman data can be observed in the histograms in Supplementary Figures S13-S16 in Plate C and Supplementary Figures S10-S12 in Plate D.

\subsubsection{Multivariate Analysis on Raman Spectra}

PCA was carried out on each sample building a matrix where each row corresponds to a different spectrum and each column to the intensity at different Raman shift. The goodness of the PCA model is expressed by the percentage of explanation for each PC. In our samples, the first two PCs components explain between the $88 \%$ and the $98 \%$ of the variance in the original matrix (Supplementary Figures S5-S8 in Plates C and Figures S4-S6 in Plate D). Generally, values higher than $80 \%$ in the first three PCs indicate acceptable models.

Plotting the two first PCs on the score plots (Supplementary Figures S1-S4 in Plates C and Figures S1-S3 in Plate D), data are usually distributed into two or three clusters with a trend along the $\mathrm{x}$ axis (i.e., first principal component). 
Loading plots in (Supplementary Figures S9-S12 in Plate C and Figures S7-S9 Plate B) indicate the frequency at which major changes in the Raman spectrum occur. Values close to zero mean that almost no changes occur, while maximum values depict the greatest variation among spectra. In our spectra the greatest variations always occur at around $1350 \mathrm{~cm}^{-1}$ and $1600 \mathrm{~cm}^{-1}$ that is the region of the $\mathrm{D}$ and $\mathrm{G}$ bands and for higher wavenumbers $\left(>1650 \mathrm{~cm}^{-1}\right)$, reflecting the increasing/decreasing fluorescence among different macerals.

In Figures 6 and $7 b, f, j$ the optically recognized vitrinite and inertinite spectra are shown on the score plots (red and yellow dots respectively). The figure shows that most of the vitrinite fragments fall in the main cluster (except for sample PL 103), while depending on the sample, inertinite usually falls in a second cluster, but shifted towards lower or higher first PC values. a)

Normalized Raman spectra

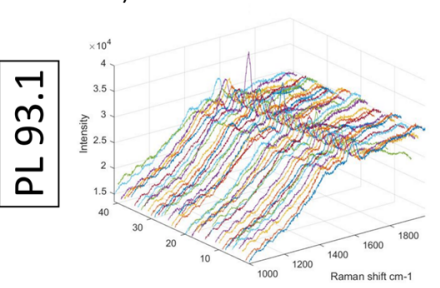

e)

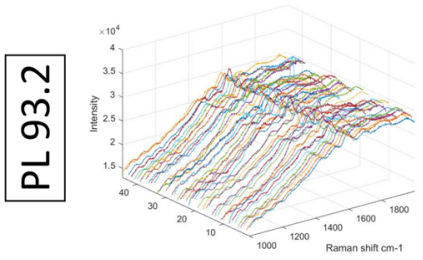

i)

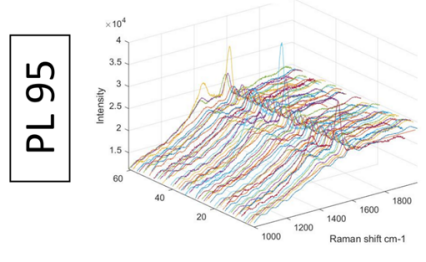

Identified macerals on the score plot

b)

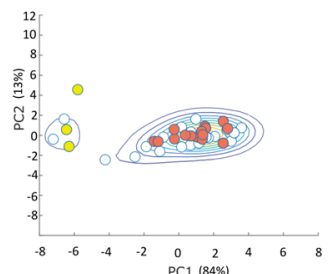

f)

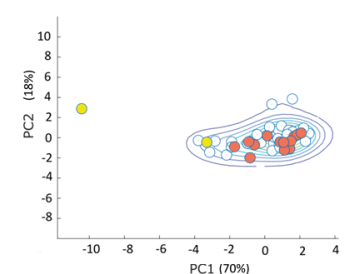

j)

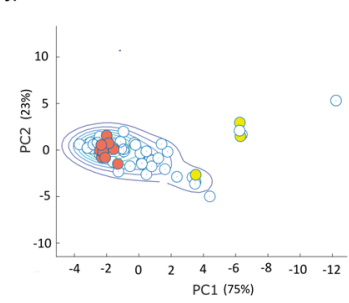

Identified macerals after PLS-DA c)

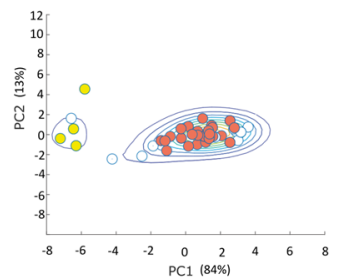

g)

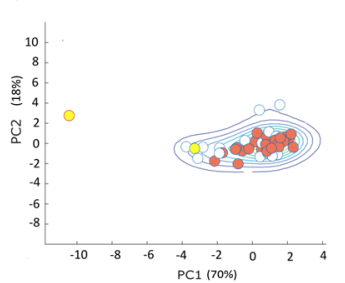

k)

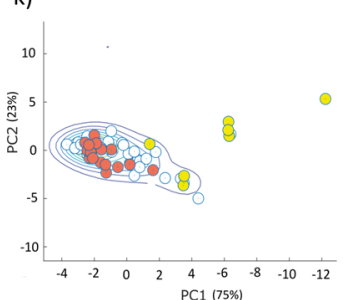

Ro equivalent from Raman parameters

d)

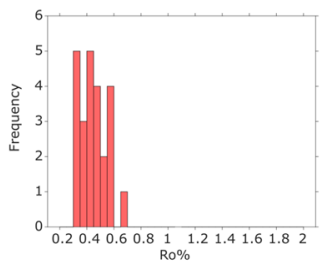

h)

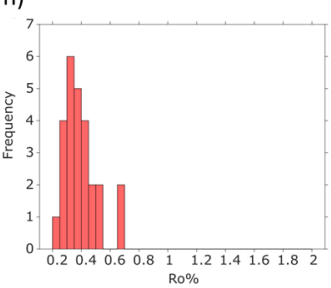

l)

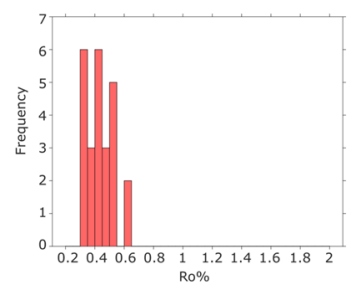

Figure 6. Results for samples PL 93.1, PL 93.2 and PL 95. Figures (a,e,i) show the raw spectra in a 3D view. Figures $(\mathbf{b}, \mathbf{f}, \mathbf{j})$ the score plots distribution: red dots indicated optically recognized vitrinite while yellow dots optically recognized inertinite. Figures (c,g,k) show optically recognized and identified after PLS-DA vitrinites (red dots) and inertinites (yellow dots); number in brackets refers to explained variance by each principal component. Figures $(\mathbf{d}, \mathbf{h}, \mathbf{l})$ histograms of $R_{0} \%$ equivalent values from Raman parameters calculated on vitrinite recognized by means of PLS-DA. 


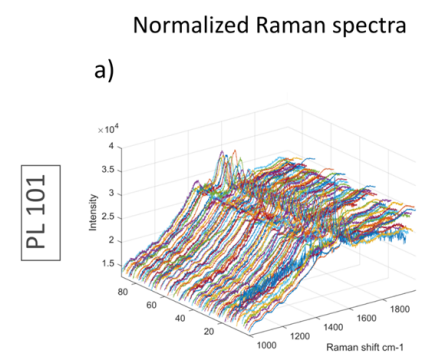

Identified macerals on the score plot

e)

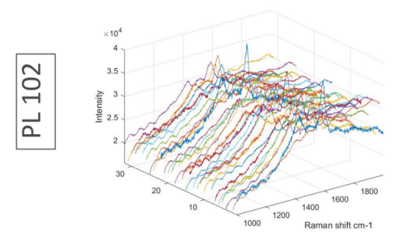

i)

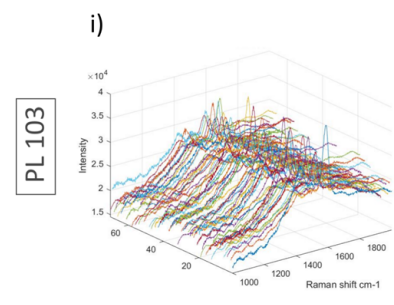

b)

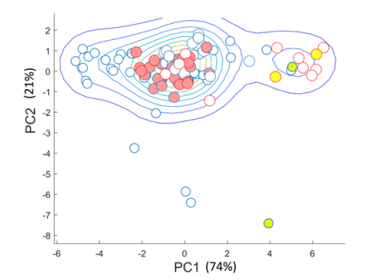

c)

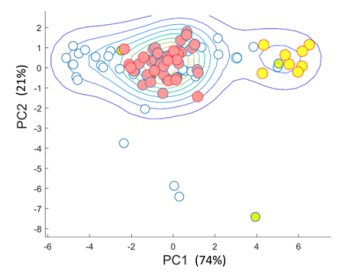

f)

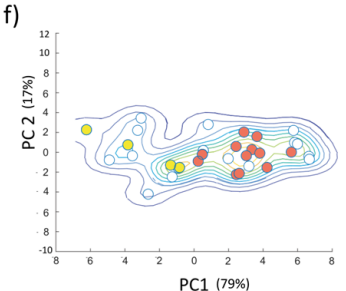

j)

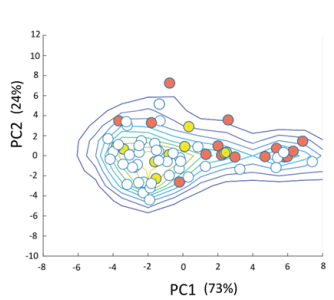

g)

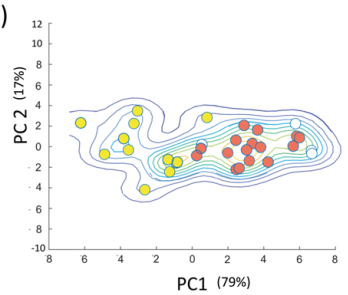

k)

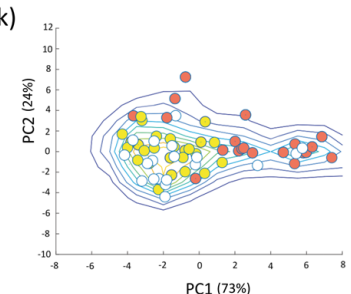

Ro equivalent from Raman parameters

d)

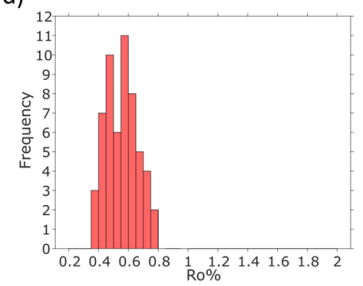

h)

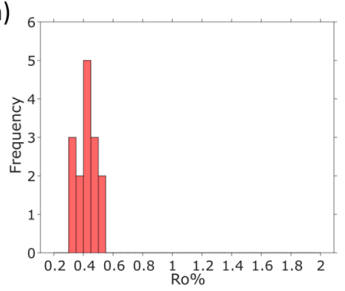

I)

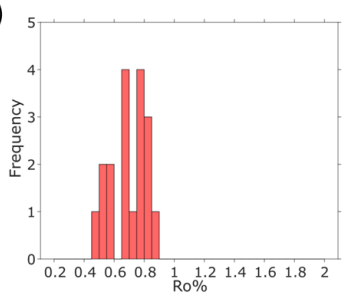

Figure 7. Results for samples PL 101, PL 102 and PL 103. Figures (a,e,i) show the raw spectra in a 3D view. Figures (b,f,j) the score plots distribution: red dots indicated optically recognized vitrinite while yellow dots optically recognized inertinite. Figures (c,g,k) show optically recognized and identified after PLS-DA vitrinites (red dots) and inertinites (yellow dots); number in brackets refers to explained variance by each principal component. Figures $(\mathbf{d}, \mathbf{h}, \mathbf{l})$ show the histograms of $R_{\mathrm{o}} \%$ equivalent values from Raman parameters calculated on vitrinite recognized by means of PLS-DA.

Based on this evidences, a multivariate classification via the PLS-DA technique was used to derive prediction parameters for the classification of vitrinite and inertinite group macerals. In a first step, vitrinite and inertinite spectra were used as a training set to build a calibration model, whose goodness was validated by means of statistic tests (see Supplementary Materials Plate E). Two statistics tests were then performed (Supplementary Materials Plate E): test (1) "Percentage of variance versus Number of PLS components"; test (2) "Mean squared prediction error (MSEP) versus Number of PLS components". Test 1 results show that three first PLS components explained between $60 \%$ to $98 \%$ of the variance (only in samples PL 101.1 and PL 103 the first three components explain less than the $80 \%$ of the variance; Supplementary Figures S4 and S6 in Plate E). Test 2 results show that the MSEP is higher for the first two components and then decreases up to its minimum in almost all samples, except for sample PL 102 (Supplementary Figure S5 in Plate E). Thus, a statistically significant number of PLS components for the training model is three, since it explains a high percent of variance with the minimum error.

Once found the right number of factors, PLS-DA was run on the training set to establish the classification parameters for each class. The obtained beta factors were applied to the test set to categorize the remaining unclassified spectra into one of the two classes. This results in an increased number of the recognized vitrinite to be measured for thermal maturity. Table 4 shows the mean reflectance equivalent values and number measurements found for recognized vitrinite macerals and for the vitrinite macerals found only after the PLS-DA analysis. 
Table 4. Measured vitrinite reflectance equivalent from Raman parameters for each sample before and after PLS-DA analyses.

\begin{tabular}{ccccccc}
\hline Sample & $\mathbf{R}_{\mathbf{o}}$ \% & $\begin{array}{c}\text { Observed } \\
\text { s.d. }\end{array}$ & Counts & $\mathbf{R}_{\mathbf{o}}$ \% $_{\mathbf{e q}}$ & s.d. & Counts \\
\hline PL 93.1 & 0.45 & 0.09 & 15 & 0.45 & 0.09 & 24 \\
PL 93.2 & 0.39 & 0.08 & 14 & 0.39 & 0.11 & 26 \\
PL 95 & 0.42 & 0.07 & 11 & 0.44 & 0.08 & 25 \\
PL 97 & 0.40 & 0.07 & 5 & - & - & - \\
PL 101.1 & 0.57 & 0.10 & 26 & 0.54 & 0.11 & 58 \\
PL 102 & 0.43 & 0.07 & 11 & 0.42 & 0.07 & 15 \\
PL 103 & 0.57 & 0.09 & 15 & 0.60 & 0.11 & 19 \\
\hline
\end{tabular}

s.d.: standard deviation.

The analysis was not performed on sample PL 97 (where only vitrinite has been recognized) since PLS-DA analysis cannot be performed on a single class.

Table 4 and Figures 6 and 7 indicate that the number of measurements on vitrinite increased from a minimum of 26\% in samples PL 102 and PL 103 up to a maximum of $123 \%$ in sample PL 101.1, whereas the mean $\mathrm{R}_{\mathrm{o}} \%$ eq values are very similar with a slightly increase in the standard deviation values (Table 4).

\section{Discussion}

\subsection{Source Rocks Quality, Organic Facies and Thermal Maturity}

The area of interest in this study is part of the wider flysch belt of the Outern Carpathians, which is one of the oldest oil-producing regions in the world [63]. In particular, the Melinite shales, buried in the Boryslav-Pokuttya tectonic unit, acted as the main oil-bearing succession in the Carpathian region and have been widely studied, in particular in the polish sector [63]. In the area analysed in this work, belonging to the Ukranian sector, less data are available and the source rocks are not fully characterized.

The quality of the outcropping source rocks can be pointed out by means of TOC, HI, and S2 values (Figure 3), whereas the degree of thermal maturity has been accurately assessed by double checking $\mathrm{R}_{\mathrm{O}} \%$ values from organic petrography with Tmax from RockEval Pyrolysis. Via these methods, we can state that black shales of the Shypot beds in the Chornogora Unit, acted as a "good to very good" mixed gas and oil prone source rock with a thermal maturity falling at the oil window onset. As well, the Krosno beds in the internal portion of the Skiba unit, show an excellent oil-prone potential according to pyrolysis data (samples PL 93.1, PL 93.2, and PL 95), whereas Tmax and $R_{\mathrm{o}} \%$ values for samples PL 101.1 indicate both good gas and oil generation potential in the window of oil generation. On the other hand, thermal maturity of samples PL 93.1, PL93.2, and PL 95 indicate immature source rocks (Table 2; Figures 3 and 4). Samples PL 97 and PL 103 from the Melinite shales, located in the external part of the Skiba Unit and Chornogora Unit respectively, show good oil potential. However, Tmax and $R_{\mathrm{O}} \%$ values point out different thermal maturity levels suggesting that maximum temperatures were acquired in each tectonic unit due to a tectonic loading during the formation of the chain rather than at the end of sedimentation.

The petrographic analysis of the polished blocks, via incident light microscopy, revealed a complex assemblage of macerals for all samples (Figure 4). A significant number of suitable vitrinite particles was found for reflectance measurements in all samples except in sample PL 97 (only 11 suitable particles). In this sample, as well as in samples PL 93.2, PL 95, and to minor extent in samples PL 102 and PL 101.1, thermal maturity assessment was complicated by the diffuse presence of macerals with similar appearance, but having weak fluorescence, lower reflectance and darker shades of grey than vitrinite and have been interpreted to belong to the liptinite group. A further complication was given by the presence in all samples of higher reflectance macerals $\left(>0.5-0.6 R_{o} \%\right.$; Figure 4$)$, which were identified as inertinite and in some cases as reworked vitrinite fragments. The inertinite particles were grouped into semifusinite $\left(R_{O}=0.6-0.8 \%\right)$ and fusinite $\left(R_{O}>1 \%\right)$. 
Vitrinite reflectance $\left(\mathrm{R}_{\mathrm{O}}=0.42-0.46 \%\right)$ and $\operatorname{Tmax}$ data $\left(421{ }^{\circ} \mathrm{C}-433{ }^{\circ} \mathrm{C}\right)$ indicate that most of the samples are in the immature stage of hydrocarbon. However, samples PL 101.1 and L 103 lie at the oil window onset with reflectance values of $0.51 \%$ and $0.61 \%$ and Tmax of 439 and 436, respectively.

\subsection{Raman Spectroscopy and Vitrinite Reflectance Equivalent $\left(R_{o} \%\right.$ eq)}

The presence of different Raman spectra shapes in each sample can be interpreted as the coexistence of in situ and reworked materials and/or of different particles of organic matter (Figure 4). Such Raman spectrum differences (Figure 5) result, after a two-band fitting deconvolution, in higher values of the distance between the $G$ and D bands and of the area, intensity and FWHM ratio of the D and G bands (Table 4). These differences are mainly due to a red-shift and a D band area and width increase accompanied by a decrease of the $\mathrm{G}$ band width, which are the result of an increase of larger aromatic clusters, passing from disordered to more ordered materials $[29,32,57,58,64,65]$, in this case, a progressive ordered structure: liptinite particles (when registered) $<$ vitrinite $<$ inertinite.

Comparing the histograms of the $\mathrm{R}_{\mathrm{O}} \%$ eq of the undifferentiated particle spectra (Supplementary Materials Plate C Figures S13-S16 and Plate D Figures S10-S12) with the $R_{0} \%$ histograms (Supplementary Materials Plate C Figures S17-S20 and Plate D Figures S13-S15), we can observe that their main modes are centred almost at the same values except for samples PL 95 and PL 97 or in PL 103 where, on the other hand, vitrinite is not the most abundant maceral. In samples PL 95 and PL 97 the $\mathrm{R}_{\mathrm{o}} \%$ histograms are slightly shifted toward lower values with respect $R_{o} \%$ eq, due to the higher number of measurements probably made on liptinites. In sample PL 103, semifusinite is the most abundant maceral, with $R_{\mathrm{O}} \%$ values very similar to those of vitrinite, and an overlap in the reflectance histogram with vitrinite in $R_{o} \%$ eq conversion (Figure 7 ). $R_{o} \%$ eq values on inertinite are usually higher than vitrinite and mostly agree with optically reflectance values measured on the same maceral. Nevertheless, we did not focus on them since the assessment of inertinite equivalent reflectance from Raman is beyond the aim of this work and useless for thermal maturity assessment and basin modeling.

\subsection{Multivariate Analyses on Raman Spectra}

Raman spectroscopy has become a promising tool for thermal maturity evaluation of coals and dispersed organic matter in diagenesis (see [66] for a comprehensive review). However, working with dispersed organic matter, the inability to couple optical observation under oil immersion, seriously limit Raman organic petrographic analyses as evidenced by the fact that only few works focus on single macerals measurements $[23,32,37,57,67]$. In this work we show how a multivariate analysis on Raman spectra can help in macerals description and identification when dealing with particularly complex organofacies.

Looking at the score plots derived from our samples, a linear trend can be generally seen, moving from negative to positive values on the first principal component axis, with a cluster of maximum density generally centered around 0 (Supplementary Materials Plate C Figures S1-S4 and Plate D Figures S1-S3). On the other hand, the variance on the second PCs axis is always limited with respect to the first. In these plots, outliers are easily recognized and can be excluded from the maturity conversion. Moreover, the score plots show two or more clusters of data. Samples with similar scores are similar and each cluster corresponds to particles with spectra showing similar "aromatization degree". When optically identified, vitrinite and inertinite macerals are plotted on the score plot (Figures 6 and 7) and vitrinite usually falls in the main cluster whereas inertinite falls in the most external part toward both more positive or negative values, depending on the relative abundance of different macerals.

Loadings plots (Supplementary Materials Plate C Figures S9-S12 and Plate D Figures S7-S9), on the other hand, show that major changes in Raman spectra among different macerals, occur at around $1350 \mathrm{~cm}^{-1}$ and $1600 \mathrm{~cm}^{-1}$ (e.g., D and G band region) and after $1700 \mathrm{~cm}^{-1}$. These changes can be related to a shift in the $\mathrm{D}$ band position, a $\mathrm{G}$ 
band narrowing and a fluorescence decrease moving from hydrogen-rich to more aromatic organic matter [32].

Once defined the different classes of spectra in the samples, the PLS-DA analysis confirms that similar macerals fall in the same cluster on the score plot allowing to classify most of the remaining spectra.

In this way the number of vitrinite fragments increase, providing a more robust thermal maturity assessment (Figures 6 and 7). In Figure 8 the average $R_{o} \%_{\text {eq }}$ values calculated from the Raman spectra of vitrinite (red circles) and for the sum of vitrinite and PLS-DA derived vitrinite (blue circles) are plotted against the microscopic determination of vitrinite reflectance $\left(R_{o} \%\right)$ together with the average $R_{o} \%$ eq calculated on the whole macerals composition (green diamonds). Despite a slight increase of the standard deviation from $R_{o} \%$ to $R_{o e q} \%$ calculated from Raman (Figure 8, Table 3), a better correlation between the mean values of both methods was found, together with an important increase of measurements after PLS-DA. The higher standard deviation of $\mathrm{R}_{\mathrm{o}} \%_{\mathrm{eq}}$ with respect to $\mathrm{R}_{\mathrm{o}} \%$ should be considered as an intrinsic limitation of the conversion equation given that the confidence interval of the equation indicates that an error higher than \pm 0.05 can be expected for each measurement (see [38]), and thus the sum of the errors in a certain thermal maturity interval probably led to a relatively high standard deviation as those observed in our samples. More detailed studies based on further datasets are needed in future to provide a more effective tool.

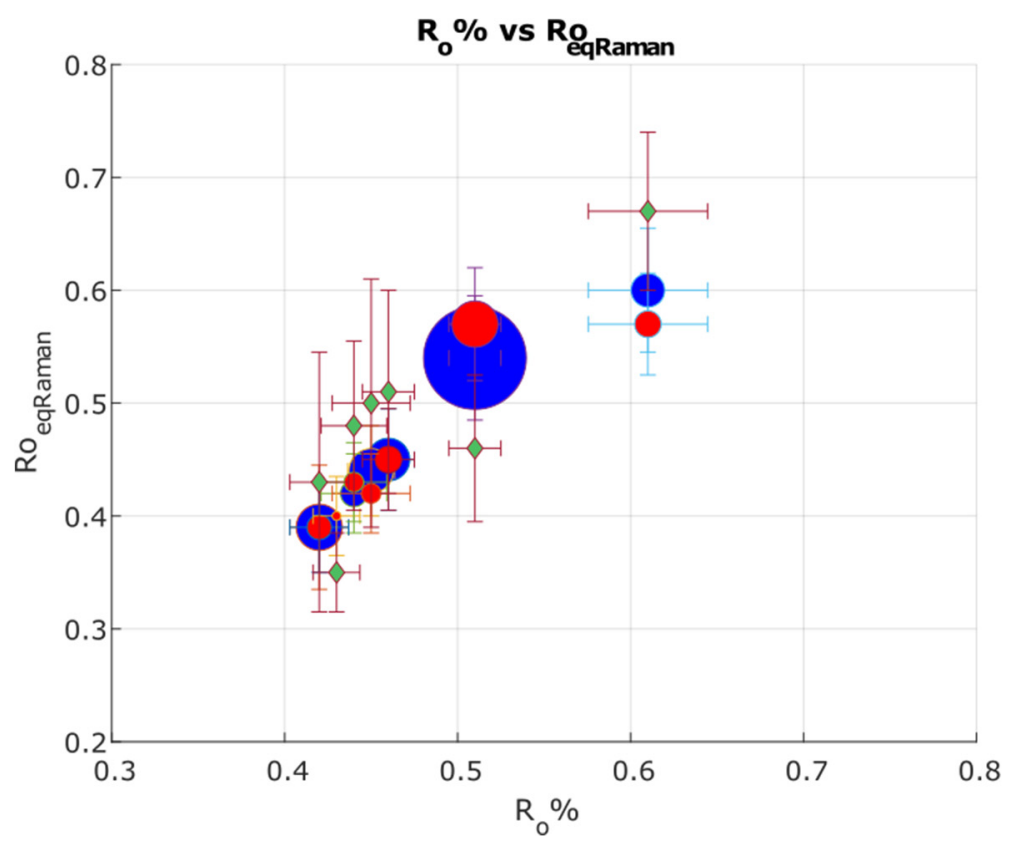

\section{Legend}

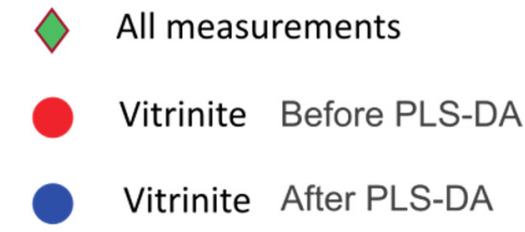

- 5 Measurements

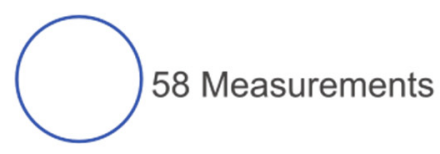

Figure 8. The diagram shows the correlation between the microscopic determination of vitrinite reflectance $\left(R_{\mathrm{O}} \%\right)$ and the reflectance equivalent of vitrinite $\left(R_{\mathrm{oeq}} \%\right)$ macerals calculated by means of Raman parameters, according to [38], for values obtained before (red circles) and after (blue circles) PLS-DA analysis. The size of the circles depends on the number of measurements for each sample. Green diamonds show $R_{\text {oeq }} \%$ values calculated on all macerals composition.

Given this, the high correlation in such a small range of thermal maturity (between about 0.4 and $0.6 \mathrm{R}_{\mathrm{o}} \%$ ) confirms Raman spectroscopy as an accurate thermal maturity tool also in low diagenesis.

\section{Conclusions}

In this work organic petrography, Raman micro-spectroscopic and Rock-Eval pyrolysis analyses were performed on a set of samples collected from Mesozoic and Cenozoic successions of the Outer sector of the Carpathian fold and thrust belt, in Ukraine. 
Organic petrography and Rock-Eval pyrolysis evidence a type II/III kerogen with complex composition characterized by the presence of macerals of the vitrinite, inertinite and liptinite groups. According to Tmax and $\mathrm{R}_{\mathrm{o}} \%$ data thermal maturity lies at the onset of the oil window spanning between about 0.40 and $0.60 R_{o} \%$ (based on 30-50 measurements on vitrinite for most of the samples).

Micro-Raman analyses were performed on a higher number of organic fragments giving back from about 30 to about 100 spectra on each sample but, only for relatively few fragments was possible an optical classification according to their macerals group. For this reason, we performed a multivariate statistical analysis in order to define the variability of the organic facies and develop a predictive PLS-DA model for the identification of vitrinite from Raman spectra.

Results demonstrate that the PLS-DA model allows to successfully classify macerals on the basis of their Raman spectrum, considerably increasing the number of fragments that can be used for thermal maturity assessment.

Following the first attempts of $[32,34,68,69]$, this work outlines how machine learning techniques can be a powerful support to classical organic petrography analyses in thermal maturity assessment on sediments where organic fragments are finely dispersed.

Supplementary Materials: The following are available online at https:/ /www.mdpi.com/article/10 .3390/geosciences11050213/s1, Plate A: Histograms of reflectance measurements made on visible macerals and on vitrinite for each sample. Plate B: 2D and 3D Raman plot of all spectra acquired for each sample. Plate C: PCA results and $R_{0} \%$ and $R_{o e q} \%$ histograms for samples PL 93.1, PL 93.2, PL95 and PL 97. Figures S1-S4: PCA Score plots; Figures S5-S8: PCA explained values for each PCs; Figures S9-S12: PCA loadings plots; Figures S13-S16: $\mathrm{R}_{\text {oeq }} \%$ histograms; Figures S17-S20: $\mathrm{R}_{\mathrm{o}} \%$ histograms. Plate D: PCA results and $\mathrm{R}_{\mathrm{o}} \%$ and $\mathrm{R}_{\mathrm{oeq}} \%$ histograms for samples PL 101.1, PL 102 and PL103. Figures S1-S3: PCA Score plots; Figures S4-S6: PCA explained values for each PCs; Figures S7-S9: PCA loadings plots; Figures S10-S12: $\mathrm{R}_{\text {oeq }} \%$ histograms; Figures S13-S15: $\mathrm{R}_{\mathrm{o}} \%$ histograms. Plate E: PLS-DA explained variance and associated Mean Square Errors (MSEP) as a function of PLS components.

Author Contributions: Conceptualization, A.S. and S.C.; methodology, A.S., A.G., and B.V.; software, A.S.; validation, A.S., B.V., and N.A.V.S.; formal analysis, A.S. and B.V.; investigation, A.S., A.G., B.V., and S.C.; resources, S.C.; data curation, A.S. and B.V.; writing-original draft preparation, A.S.; writing—review and editing, S.C., B.V., A.G., and N.A.V.S.; visualization, A.S., A.G., B.V., and S.C.; supervision, S.C.; project administration, S.C.; funding acquisition, S.C. All authors have read and agreed to the published version of the manuscript.

Funding: This research was funded by: MIUR Roma Tre Postdoctoral Grant (2017-2020) n ${ }^{\circ}$ rep. REP. 22-PROT. 219 of the 26/01/2017.

Institutional Review Board Statement: Not applicable.

Informed Consent Statement: Not applicable.

Data Availability Statement: Raman data resulting from spectra fitting are available at the following link: 10.6084/m9.figshare.14251025.

Acknowledgments: Jankowski L., Mazzoli S., Szaniawski R., and Zattin M. are warmly ackowledged for their help in the sampling campaign and stimulating discussions on Carphatians geology. D. Grigo is kindly thanked for constant encouragement during the work and fruitful discussions on thermal modelling. ENI is acknowledged for pyrolysis data (already presented in the first Author's $\mathrm{PhD}$ thesis) produced in Bolgiano Laboratories and for sponsoring the sampling campaign. The Grant of Excellence Departments, MIUR (ARTICOLO 1, COMMI 314-337 LEGGE 232/2016), is gratefully acknowledged.

Conflicts of Interest: The authors declare no conflict of interest. 


\section{References}

1. Hackley, P.C.; Cardott, B.J. Application of organic petrography in North American shale petroleum systems: A review. Int. J. Coal Geol. 2016, 163, 8-51. [CrossRef]

2. Lucca, A.; Storti, F.; Molli, G.; Muchez, P.; Schito, A.; Artoni, A.; Balsamo, F.; Corrado, S.; Mariani, E.S. Seismically enhanced hydrothermal plume advection through the process zone of the Compione extensional Fault, Northern Apennines, Italy. Bull. Geol. Soc. Am. 2018, 131, 547-571. [CrossRef]

3. Bullock, L.; Parnell, J.; Muirhead, D.; Armstrong, J.; Schito, A.; Corrado, S. A thermal maturity map based on vitrinite reflectance of british coals. J. Geol. Soc. 2019, 176, 1136-1142. [CrossRef]

4. Corrado, S.; Aldega, L.; Perri, F.; Critelli, S.; Muto, F.; Schito, A.; Tripodi, V. Detecting syn-orogenic extension and sediment provenance of the Cilento wedge top basin (southern Apennines, Italy): Mineralogy and geochemistry of fine-grained sediments and petrography of dispersed organic matter. Tectonophysics 2019, 750, 404-418. [CrossRef]

5. Balestra, M.; Corrado, S.; Aldega, L.; Rudkiewicz, J.-L.; Morticelli, M.G.; Sulli, A.; Sassi, W. 3D structural modeling and restoration of the Apennine-Maghrebian chain in Sicily: Application for non-cylindrical fold-and-thrust belts. Tectonophysics 2019, 761, 86-107. [CrossRef]

6. Bensley, D.F.; Crelling, J.C. The inherent heterogeneity within the vitrinite maceral group. Fuel 1994, 73, 1306-1316. [CrossRef]

7. Malinconico, M.L. Using reflectance crossplots and rotational polarization for determining first-cycle vitrinite for maturation studies. Int. J. Coal Geol. 2000, 43, 105-120. [CrossRef]

8. Mählmann, R.F.; Le Bayon, R. Vitrinite and vitrinite like solid bitumen reflectance in thermal maturity studies: Correlations from diagenesis to incipient metamorphism in different geodynamic settings. Int. J. Coal Geol. 2016, 157, 52-73. [CrossRef]

9. Hackley, P.C.; Valentine, B.J.; Hatcherian, J.J. On the petrographic distinction of bituminite from solid bitumen in immature to early mature source rocks. Int. J. Coal Geol. 2018, 196, 232-245. [CrossRef]

10. Schmidt, J.S.; Menezes, T.R.; Souza, I.V.A.F.; Spigolon, A.L.D.; Pestilho, A.L.S.; Coutinho, L.F.C. Comments on empirical conversion of solid bitumen reflectance for thermal maturity evaluation. Int. J. Coal Geol. 2019, 201, 44-50. [CrossRef]

11. Atouabat, A.; Corrado, S.; Schito, A.; Haissen, F.; Gimeno-Vives, O.; Mohn, G.; Frizon de Lamotte, D. Validating Structural Styles in the Flysch Basin Northern Rif (Morocco) by Means of Thermal Modeling. Geosciences 2020, 10, 325. [CrossRef]

12. Suarez-Ruiz, I.; Flores, D.; Mendonca Filho, J.G.; Hackley, P.C. Review and update of the applications of organic petrology: Part 1, geological applications. Int. J. Coal Geol. 2012, 99, 54-112.

13. Schito, A.; Corrado, S.; Aldega, L.; Grigo, D. Overcoming pitfalls of vitrinite reflectance measurements in the assessment of thermal maturity: The case history of the lower Congo basin. Mar. Pet. Geol. 2016, 74, 59-70. [CrossRef]

14. Spina, A.; Vecoli, M.; Riboulleau, A.; Clayton, G.; Cirilli, S.; Di Michele, A.; Marcogiuseppe, A.; Rettori, R.; Sassi, P.; Servais, T. Application of Palynomorph Darkness Index (PDI) to assess the thermal maturity of palynomorphs: A case study from North Africa. Int. J. Coal Geol. 2018, 188, 64-78. [CrossRef]

15. Sorci, A.; Cirilli, S.; Clayton, G.; Corrado, S.; Hints, O.; Goodhue, R.; Schito, A.; Spina, A. Palynomorph optical analyses for thermal maturity assessment of Upper Ordovician ( Katian-Hirnantian ) rocks from Southern Estonia. Mar. Pet. Geol. 2020, 120, 104574. [CrossRef]

16. Ganz, H.H.; Kalkreuth, W. IR classification of kerogen type, thermal maturation, hydrocarbon potential and lithological characteristics. J. Southeast Asian Earth Sci. 1991, 5, 19-28. [CrossRef]

17. Landais, P.; Rochdi, A.; Largeau, C.; Derenne, S. Chemical characterization of torbanites by transmission micro-FTIR spectroscopy: Origin and extent of compositional heterogeneities. Geochim. Cosmochim. Acta 1993, 57, 2529-2539. [CrossRef]

18. Lis, G.P.; Mastalerz, M.; Schimmelmann, A.; Lewan, M.D.; Stankiewicz, B.A. FTIR absorption indices for thermal maturity in comparison with vitrinite reflectance R0 in type-II kerogens from Devonian black shales. Org. Geochem. 2005, 36, 1533-1552. [CrossRef]

19. Di Paolo, L.; Aldega, L.; Corrado, S.; Mastalerz, M. Maximum burial and unroofing of Mt. Judica recess area in Sicily: Implication for the Apenninic-Maghrebian wedge dynamics. Tectonophysics 2012, 530, 193-207. [CrossRef]

20. Corrado, S.; Schito, A.; Romano, C.; Grigo, D.; Poe, B.T.; Aldega, L.; Caricchi, C.; Paolo, D.; Zattin, M. An integrated platform for thermal maturity assessment of polyphase, long-lasting sedimentary basins, from classical to brand-new thermal parameters and models: An example from the on-shore Baltic Basin (Poland). Mar. Pet. Geol. 2020, 122, 104547. [CrossRef]

21. Kelemen, S.R.; Afeworki, M.; Gorbaty, M.L.; Sansone, M.; Kwiatek, P.J.; Walters, C.C.; Freund, H.; Siskin, M.; Bence, A.E.; Curry, D.J. Direct characterization of kerogen by X-ray and solid-state 13C nuclear magnetic resonance methods. Energy Fuels 2007, 21, 1548-1561. [CrossRef]

22. Valentim, B.; Guedes, A.; Boavida, D. Nitrogen functionality in "oil window" rank range vitrinite rich coals and chars. Org. Geochem. 2011, 42, 502-509. [CrossRef]

23. Guedes, A.; Valentim, B.; Prieto, A.C.; Rodrigues, S.; Noronha, F. Micro-Raman spectroscopy of collotelinite, fusinite and macrinite. Int. J. Coal Geol. 2010, 83, 415-422. [CrossRef]

24. Hinrichs, R.; Brown, M.T.; Vasconcellos, M.A.Z.; Abrashev, M.V.; Kalkreuth, W. Simple procedure for an estimation of the coal rank using micro-Raman spectroscopy. Int. J. Coal Geol. 2014, 136, 52-58. [CrossRef]

25. Muirhead, D.K.; Bond, C.E.; Watkins, H.; Butler, R.W.H.; Schito, A.; Crawford, Z.; Marpino, A. Raman Spectroscopy: An effective thermal marker in low temperature carbonaceous fold-thrust belts. Geol. Soc. London, Spec. Publ. 2019, 490, 135-151. [CrossRef] 
26. Wilkins, R.W.T.; Boudou, R.; Sherwood, N.; Xiao, X. International Journal of Coal Geology Thermal maturity evaluation from inertinites by Raman spectroscopy: The 'RaMM'technique. Int. J. Coal Geol. 2014, 128, 143-152. [CrossRef]

27. Wilkins, R.W.T.; Sherwood, N.; Li, Z. RaMM (Raman maturity method) study of samples used in an interlaboratory exercise on a standard test method for determination of vitrinite reflectance on dispersed organic matter in rocks. Mar. Pet. Geol. 2018, 91, 236-250. [CrossRef]

28. Lünsdorf, N.K.; Dunkl, I.; Schmidt, B.C.; Rantitsch, G.; von Eynatten, H. Towards a Higher Comparability of Geothermometric Data Obtained by Raman Spectroscopy of Carbonaceous Material. Part 2: A Revised Geothermometer. Geostand. Geoanalytical Res. 2017, 41, 593-612. [CrossRef]

29. Schito, A.; Romano, C.; Corrado, S.; Grigo, D.; Poe, B. Diagenetic thermal evolution of organic matter by Raman spectroscopy. Org. Geochem. 2017, 106, 57-67. [CrossRef]

30. Schito, A.; Corrado, S.; Trolese, M.; Aldega, L.; Caricchi, C.; Cirilli, S.; Grigo, D.; Guedes, A.; Romano, C.; Spina, A.; et al. Assessment of thermal evolution of Paleozoic successions of the Holy Cross Mountains (Poland). Mar. Pet. Geol. 2017, 80, 112-132. [CrossRef]

31. Schmidt, J.S.; Hinrichs, R.; Araujo, C.V. Maturity estimation of phytoclasts in strew mounts by micro-Raman spectroscopy. Int. J. Coal Geol. 2017, 173, 1-8. [CrossRef]

32. Schito, A.; Spina, A.; Corrado, S.; Cirilli, S.; Romano, C. Comparing optical and Raman spectroscopic investigations of phytoclasts and sporomorphs for thermal maturity assessment: The case study of Hettangian continental facies in the Holy cross Mts. (central Poland). Mar. Pet. Geol. 2019, 104, 331-345. [CrossRef]

33. Henry, D.G.; Jarvis, I.; Gillmore, G.; Stephenson, M. Raman spectroscopy as a tool to determine the thermal maturity of organic matter: Application to sedimentary, metamorphic and structural geology. Earth Sci. Rev. 2019, 198, 102936. [CrossRef]

34. Bonoldi, L.; Frigerio, F.; Di Paolo, L.; Savoini, A.; Barbieri, D.; Grigo, D. Organic Matter Maturity Profile of a Well Case Study by Combination of Raman Spectroscopy and Principal Component Analysis-Partial Least Squares Regression (PCA-PLS) Chemometric Methods. Energy Fuels 2018, 32, 8955-8965. [CrossRef]

35. Zhou, Q.; Xiao, X.; Pan, L.; Tian, H. The relationship between micro-Raman spectral parameters and reflectance of solid bitumen. Int. J. Coal Geol. 2014, 121, 19-25. [CrossRef]

36. Lupoi, J.S.; Fritz, L.P.; Hackley, P.C.; Solotky, L.; Weislogel, A.; Schlaegle, S. Quantitative evaluation of vitrinite reflectance and atomic $\mathrm{O} / \mathrm{C}$ in coal using Raman spectroscopy and multivariate analysis. Fuel 2018, 230, 1-8. [CrossRef]

37. Jubb, A.M.; Botterell, P.J.; Birdwell, J.E.; Burruss, R.C.; Hackley, P.C.; Valentine, B.J.; Hatcherian, J.J.; Wilson, S.A. High microscale variability in Raman thermal maturity estimates from shale organic matter. Int. J. Coal Geol. 2018, 199, 1-9. [CrossRef]

38. Schito, A.; Corrado, S. An automatic approach for characterization of the thermal maturity of dispersed organic matter Raman spectra at low diagenetic stages. Geol. Soc. London, Spec. Publ. 2018, 484, 107-119. [CrossRef]

39. Khatibi, S.; Ostadhassan, M.; Tuschel, D.; Gentzis, T.; Bubach, B.; Carvajal-Ortiz, H. Raman spectroscopy to study thermal maturity and elastic modulus of kerogen. Int. J. Coal Geol. 2018, 185, 103-118. [CrossRef]

40. Henry, D.G.; Jarvis, I.; Gillmore, G.; Stephenson, M.; Emmings, J.F. International Journal of Coal Geology Assessing low-maturity organic matter in shales using Raman spectroscopy: E ff ects of sample preparation and operating procedure. Int. J. Coal Geol. 2018, 191, 135-151. [CrossRef]

41. Hackley, P.C.; Lünsdorf, N.K. Application of raman spectroscopy as thermal maturity probe in shale petroleum systems: Insights from natural and artificial maturation series. Energy Fuels 2018, 32, 11190-11202. [CrossRef]

42. Schito, A.; Aldega, L.; Corrado, S.; Di Paolo, L.; Gangemi, G. Thermal evolution of Paleozoic and Mesozoic-Cenozoic successions of the Carpathian orogenic system (central sector-Ukraine) from the fold and thrust belt to the foreland by means of organic petrography, spectroscopy and XR Diffraction: Preliminary resul. Rend. Online Soc. Geol. Ital. 2013, 29, 162-164.

43. Jankowski, L.; Kopciowski, R.; Rylko, W. Geological Map of the Outer Carpathians: Borderland of Ukraine and Romani 1: 200 000; Ministry of the Environment: Tokyo, Janpan, 2007.

44. Behar, F.; Beaumont, V.; Penteado, H.L.D.B. Rock-Eval 6 technology: Performances and developments. Oil Gas Sci. Technol. 2001, 56, 111-134. [CrossRef]

45. Robl, T.L.; Davis, B.H. Comparison of the HF-HCl and HF-BF3 maceration techniques and the chemistry of resultant organic concentrates. Org. Geochem. 1993, 20, 249-255. [CrossRef]

46. Standard, A. Standard Practice for Preparing Coal Samples for Microscopical Analysis by Reflected Light; ASTM International: West Conshohocken, PA, USA, 2011.

47. Standard, A. Standard Test Method for Microscopical Determination of the Reflectance of Vitrinite Dispersed in Sedimentary Rocks; ASTM International: West Conshohocken, PA, USA, 2014.

48. Tuinstra, F.; Koenig, J.L. Raman Spectrum of Graphite. J. Chem. Phys. 1970, 53, 1126-1130. [CrossRef]

49. Li, C.-Z. Some recent advances in the understanding of the pyrolysis and gasification behaviour of Victorian brown coal. Fuel 2007, 86, 1664-1683. [CrossRef]

50. Potgieter-Vermaak, S.; Maledi, N.; Wagner, N.; Van Heerden, J.H.P.; Van Grieken, R.; Potgieter, J.H. Raman spectroscopy for the analysis of coal: A review. J. Raman Spectrosc. 2011, 42, 123-129. [CrossRef]

51. Pócsik, I.; Hundhausen, M.; Koós, M.; Ley, L. Origin of the D peak in the Raman spectrum of microcrystalline graphite. J. Non. Cryst. Solids 1998, 227, 1083-1086. [CrossRef] 
52. Reich, S.; Thomsen, C. Raman spectroscopy of graphite. Philos. Trans. R. Soc. London. Ser. A Math. Phys. Eng. Sci. 2004, 362, 2271-2288. [CrossRef]

53. Pimenta, M.A.; Dresselhaus, G.; Dresselhaus, M.S.; Cancado, L.G.; Jorio, A.; Saito, R. Studying disorder in graphite-based systems by Raman spectroscopy. Phys. Chem. Chem. Phys. 2007, 9, 1276-1290. [CrossRef] [PubMed]

54. Negri, F.; Di Donato, E.; Tommasini, M.; Castiglioni, C.; Zerbi, G.; Müllen, K. Resonance Raman contribution to the D band of carbon materials: Modeling defects with quantum chemistry. J. Chem. Phys. 2004, 120, 11889-11900. [CrossRef]

55. Castiglioni, C.; Mapelli, C.; Negri, F.; Zerbi, G. Origin of the D line in the Raman spectrum of graphite: A study based on Raman frequencies and intensities of polycyclic aromatic hydrocarbon molecules. J. Chem. Phys. 2001, 114, 963-974. [CrossRef]

56. Di Donato, E.; Tommasini, M.; Fustella, G.; Brambilla, L.; Castiglioni, C.; Zerbi, G.; Simpson, C.D.; Müllen, K.; Negri, F. Wavelength-dependent Raman activity of D2h symmetry polycyclic aromatic hydrocarbons in the D-band and acoustic phonon regions. Chem. Phys. 2004, 301, 81-93. [CrossRef]

57. Lünsdorf, N.K. Raman spectroscopy of dispersed vitrinite-Methodical aspects and correlation with reflectance. Int. J. Coal Geol. 2016, 153, 75-86. [CrossRef]

58. Rebelo, S.L.H.; Guedes, A.; Szefczyk, M.E.; Pereira, A.M.; Araújo, J.P.; Freire, C. Progress in the Raman spectra analysis of covalently functionalized multiwalled carbon nanotubes: Unraveling disorder in graphitic materials. Phys. Chem. Chem. Phys. 2016, 18, 12784-12796. [CrossRef]

59. Ferralis, N.; Matys, E.D.; Knoll, A.H.; Hallmann, C.; Summons, R.E. Rapid, direct and non-destructive assessment of fossil organic matter via microRaman spectroscopy. Carbon 2016, 108, 440-449. [CrossRef]

60. Sadezky, A.; Muckenhuber, H.; Grothe, H.; Niessner, R.; Pöschl, U. Raman microspectroscopy of soot and related carbonaceous materials: Spectral analysis and structural information. Carbon 2005, 43, 1731-1742. [CrossRef]

61. Romero-Sarmiento, M.-F.; Rouzaud, J.-N.; Bernard, S.; Deldicque, D.; Thomas, M.; Littke, R. Evolution of Barnett Shale organic carbon structure and nanostructure with increasing maturation. Org. Geochem. 2014, 71, 7-16. [CrossRef]

62. Abdullah, W.H.; Togunwa, O.S.; Makeen, Y.M.; Hakimi, M.H.; Mustapha, K.A.; Baharuddin, M.H.; Sia, S.G.; Tongkul, F. Hydrocarbon source potential of Eocene-Miocene sequence of Western Sabah, Malaysia. Mar. Pet. Geol. 2017, 83, 345-361. [CrossRef]

63. Kotarba, M.J.; Koltun, Y.V. The origin and habitat of hydrocarbons of the Polish and Ukrainian Parts of the Carpathian Province. AAPG Memoir. 2006, 84, 395-442.

64. Ferrari, A.; Robertson, J. Interpretation of Raman spectra of disordered and amorphous carbon. Phys. Rev. B 2000, 61, 14095-14107. [CrossRef]

65. Castiglioni, C.; Tommasini, M.; Zerbi, G. Raman spectroscopy of polyconjugated molecules and materials: Confinement effect in one and two dimensions. Philos. Trans. R. Soc. A Math. Phys. Eng. Sci. 2004, 362, 2425-2459. [CrossRef] [PubMed]

66. Henry, D.G.; Jarvis, I.; Gillmore, G.; Stephenson, M. A rapid method for determining organic matter maturity using Raman spectroscopy: Application to Carboniferous organic-rich mudstones and coals. Int. J. Coal Geol. 2019, 203, 87-98. [CrossRef]

67. Khatibi, S.; Ostadhassan, M.; Hackley, P.; Tuschel, D.; Abarghani, A.; Bubach, B. Understanding organic matter heterogeneity and maturation rate by Raman spectroscopy. Int. J. Coal Geol. 2019, 206, 46-64. [CrossRef]

68. Lupoi, J.S.; Fritz, L.P.; Parris, T.M.; Hackley, P.C.; Solotky, L.; Eble, C.F.; Schlaegle, S. Assessment of thermal maturity trends in Devonian-Mississippian source rocks using Raman spectroscopy: Limitations of peak-fitting method. Front. Energy Res. 2017, 5, 24. [CrossRef]

69. Lupoi, J.S.; Hackley, P.C.; Birsic, E.; Fritz, L.P.; Solotky, L.; Weislogel, A.; Schlaegle, S. Quantitative evaluation of vitrinite reflectance in shale using Raman spectroscopy and multivariate analysis. Fuel 2019, 254, 115573. [CrossRef] 